\title{
O POETA NA CASA DO REI
}

\author{
Jacyntho Lins Brandão \\ Universidade Federal de Minas Gerais
}

Résumé

Cette étude, centré sur les rapports entre le poête et ses recepteurs, a pour objet la réflexion sur les concepts de poésie, de poéte et de poéme chez Pindare. Le statut du poète s'établit par rapport a celui des dieux, des héros, des rois et des vainqueurs au jeux. N'appartenant pas par origine à ce monde aristocratique, le poète y est introduit parce qu'il participe de la nature de l'ariston. On utilise dans l'analyse les trois premières Olymplques, écrites en 476 av.C., dans la pérlode la plus productive et la plus brillante de la carrière de Pindare, au moment de son arrivée en Siclle, où il est accueilli como hote (xénos) dans la cour de Théron d'Agrigente et de Hiéron de Syracuse. 
Mais que a maioria dos outros autores da literatura grega, a obra de PIndaro exi- ge do leitor o esforço constante e pacífico da ruminaçáo, a fim de que possa atinar com o sentido que a movimenta. Sem dúvida, uma atitude contrária à própria natureza dos textos, cuja finalidade se ata à festa, ao canto $\theta$ à dança, ao movimento rápido do espetáculo que thes imprime determinada feição. Tenderia a ver nisso o próprio motivo da dificuldade que os poemas de Pindaro colocam para o leitor, ou seja, o motivado pelo fato de uma peça destinada à apresentação festiva (ou à representaçáo, à mimese da fala no canto e na dança) permanecer como poema que se lé. Que se lê e se destrincha, relendo $\theta$ ruminando. Evidentemente, procede-se a um deslocamento de consequénclas marcantes para a recepçáo do texto, desvia-se seu sentido e modifica-se seu efeito estético. No embaraço, as dificuldades crescem $\theta$ o texto assim deslocado coloca problemas sobre problemas a exigir reflexão.

A realizaçăo imediata do texto como espetáculo deveria dar ocasião a experiências bem diversas: sem leltura, sem retomada do anterior, sem releitura, deveria prevalecer o impacto do conjunto dito e cantado e dançado na efetivaçăo da festa. Isso supóe que o recebedor ideal do poema não se rebela contra o ritmo do texto, que o próprío ritmo $\theta$ que dá seu sentido. Entendo por ritmo não apenas a cadéncia melódica, marcada musicalmente, a que as palavras se fazem adequadas, mas igualmente a estrutura de pensamento que nasce dessas palavras $\theta$ transmite ao ouvinte um determinado conteúdo. Muito da dificuldade que a poesia de PIndaro gera estaria justamente no decompasso de, tomada como um texto para leitura (e leitura silenciosa), busca-se nela uma estrutura discursiva e năo musical. Quando muito, admite-se o dado de que ao texto acompanharia uma melodia, mas raramente se busca tirar todas as conseqüenclas desse fato. O que é natural, na medida em que, perdida a noçăo melódica e podendo o ritmo apenas parcialmente ser reproduzido, os poemas passem à tradição como textos literários, escritos.

$E$ interessante ressaltar 0 aspecto de que so o poema, como resultado da funçăo de composiçăo da obra, perdure e seja transmitido a prosperidade. Tudo leva a crer que, ligados a uma festa singular, os epiniclos de Pindaro teriam sido apresentados (com canto $\theta$ dança) uma única vez. Assim, na realização plena de uma práxis em funçáo da qual foram compostos, săo obras efêmeras, no sentido mais rigoroso do termo: obras de um dia. Náo um dia qualquer, mas um dia de festa, a qual predisporia o público para receber de uma certa forma o poema. Dificilmente poderemos atinar com a singularidade dessa situaçăo, que orientarla uma determinada experiência estética $\theta$ uma determinada compreensáo da obra. A rigor, portanto, o seu sentido, surgido da trf plice estrutura envolvendo a realização, a experiência e a compreensão, escapa-nos Inevitavelmente. O fato de a realizaçáo da obra ter sido completa apenas na primeira ocasiăo, cria a distância radical entre a experiéncia e a compreensáo dos recebedores aos quais o poeta se dirigiria preferencialmente, isto 6,0 número reduzido dos participantes da festa, $\theta$ a experiéncla e a compreensáo de todos os outros recebedores que năo se incluem nesse grupo. Em vista disso, năo seriam, basicamente, nem a distância no tempo nem as vicissitudes da transmissăo que dificultarlam a experiéncia $\theta$ compro 
ensão de Pindaro para nós. Seria antes essa circunstância comum a todos os exclufdos da festa, contemporâneos do próprio poeta ou náo.

Ora, o fato de a realizaçáo plena da ode epinicia ser, por natureza, efêmera, levanta o problema da perenidade e da fama, do qual depende o da legitimidade de sua leitura fora do ambiente da festa. Perenidade e fama săo categorias que se realizam no tempo mas transcendem o tempo. Isso quer dizer que, atravessando o tempo, năo se submetem à vicissitude da efemeridade temporal. Pelo texto perenizado na escrita e pela fama que cobre esta perenizaçáo e a pessoa do poeta, a efeméride deixa de ser mero acidente temporal. Decerto toda literatura grega mais arcaica tem a marca da efeméride, a que se ata sua realizaçáo e, por conseqüência, sua experiência $\theta$ compreensăo. Mas no epinício $\theta$ que essa característica assume forma mais radical: os poemas homéricos bem como a maior parte dos poemas líricos deviam realizar-se pelo canto (e dança, se fosse o caso) diversas vezes, sua própria destinaçăo comporta isso; o teatro, embora como o epinficio ligado à festa, mas năo necessariamente apenas a uma única festa determinada, podia voltar a ser realizado em representaçóes sucessivas, como parece ter acontecido na própria Antigüidade, o que seu feitio permite. Já o epinicio se prende a uma circunstância singular, a uma efeméride única da vida de uma personagem única. Cada vitória de cada vitorioso exige um poema, ou seja, o poema existe para uma única vitória de um único vitorioso'. É pois impossivel a realização plena da obra mais de uma vez - $\theta$ com grande margem de probabilidade podemos admitir que apenas uma única vez tenha acontecido isso com as odes epinicias de Pindaro.

Mas a impossibilidade da repetiçăo factual da efeméride năo impossibilita perenizaçăo $\theta$ a fama, pela superaçăo da efeméride factual na efeméride que o próprio texto perpetua. O texto, assim, deixa de ser mero produto da efeméride, para tomar-se seu produtor. É a vitória de Hieráo de Siracusa, na corrida de cavalos, em Olímpia, no ano de 476, que dá ocasiăo à 1a. Olimpica; mas é na perenizaçăo do poema que tal vitória se alça a um nivel diferente, escapa da efeméride do tempo e se inscreve nas efemérides da fama.

Desse modo, tornam-se problemáticas as próprlas relaçбes do poema com a efeméride: produzido em funçăo dela, ele sobrevive a ela e fá-la sobreviver em funçăo dele próprio. Ou seja, o poema náo se reduz a uma práxis mas, enquanto texto, inscriçăo, preserva certa carga de virtualidade que o abre para novas possibilidades de experiéncla e compreensăo por outros recebedores. Os

“...docessoantes hinos

princlpio de posterior fama

são o fiel testemunho

1 - Na verdade, segundo a concepçáo do próprio poeta, ele deve celebrar com cantos cada vitória. Na abertura da 10a. OIImpica (mais exatamente na primeira antistrofe), o poeta se refere a es. se dever (bathỳ khréos) cujo atraso no cumprimento o poema vem saldar. 
de grandes virtudes" $(X I, 4-7){ }^{2}$

A definiçăo, assim concisa, colocada no infcio da 11a. Olimpica, toca diretamente no cerne da questão: năo săo as megálai aretal (grandes virtudes) que produzem a fama, mas os meligáryes hymnoi (docessoantes hinos). A areté que brilha na ação e se consubstáncia na vitória pertence ao domínio da efeméride. $O$ que fundamenta a fama é o canto, ao transferir o efêmero para a categoria do perene. O hymnos é arkhá da posterior fama, o que pode ser entendido, de um lado, tanto no sentido de que ele $\theta$ seu comesco, sua origem, seu fundamento, quanto sua causa primeira, seu ponto de partida e seu término; mais ainda, a hystéron arkhà lógon poderia ser lida como o dominio sobre a posterior fama, o poder $\theta$ a autoridade sobre ela ou, em sentido decorrente destes, como o reino da futura fama (ou do futuro discurso). $E$ portanto o hino que engendra, principia, governa e reina sobre o logos futuro. Visando a posteridade (to hysteron), o hino transcende a efeméride do feito como testemunho digno de fé. Por ele $\theta$ que 0 vabr da areté adquire confiabilidade $\theta$, conseqüentemente, renome. Os cantos epinicios dessa perspectiva se fazem o reino da posteridade.

Nåo se deve portanto estranhar que, a par de referências ao caráter efémero do canto, ligado à festa singular, as quais abundam nas odes epinfcias de Pindaro, existam outras figuras que insistem em seu caráter concreto $\theta$, por isso mesmo, duradouro. $\mathrm{Na}$ acima referida 11a. Olimplca, os versos melodiosos săo postos em pé de igualdade com a "coroa de dourada olveira" recebida como prêmio por Agesì amo (v.13-14); na sétima, săo como uma "peça de ouro maciço" que um homem opulento oferece ao jovem noivo (v.5-6); na sexta, o poema é um érgon que "como admirável palácio" se constrói (v.1-5); na 2a. Pftica, é conforme uma "mercadoria fenícia" enviada ao rei, pelo poeta, através do cinzento mar (v.125-126); na sexta, para os vitoriosos constrói-se (tetelkhistal) um "tesouro de hinos", contra o qual nada podem as intemperies (v.7-14). A suposta gravação da 7a. Olimpica, em letras de ouro, no templo de Atena, em Lindos ${ }^{3}$, representaria assim a efetivaçăo radical de uma concretude que a própria poesia de Pindaro relvindica para si4.

Apenas por ser um objeto concreto o epinicio e capaz de cumprir inteiramente sua funçăo comunicativa, passando de um lugar a outro como mercadoria. $\mathrm{Na} \mathbf{5 a}$. Neméla, com efeito, o poeta declara ser năo um estatuário, que produz figuras estáticas sobre sua base, defendendo para o poema um estatuto de bem que pode ser transportado, através dos mares, a fim de espalhar a gibria do vitorioso (v.1-6). Ora, isso evidencia que, para o proprio poeta, o texto escrito, fora do ambiente da festa, além de efeméride, tem uma funçăo, a diangelfa (divulgação, proclamaçăo, informaçăo). Ele $\theta$, de fato, Inscriçăo da vitória e da festa, visando à sua difusấo e fama, que reproduz a inscriçáo efetivada pelas mesmas no próprio esplrtto do poeta, como se afirma na

2 - As cltaços remetem sempre aos textos estabelecidos por A. Puech (PIndare, tome I: Olymplques Parls, Belles Lettes, 1970; tome ll: Pythlques, 1955; tome Ill: Nemeennes, 1952; tome IV: Isthmiques et Fragments, 1952.)

3 - A tradiçấo é transmitida pelo escollasta Gorgon , autor de um tratado peri thysion, do I seculo a.C. (Cf. Ateneu, 697 a; apud Puech, 1970, p. 88)

4 - Vejam-se as interessantes consideraçóes de D. Malhadas em Plndaro, Odes aos princlpes da Sicllia, Araraquara, UNESP, 1976, p. 70, nota 3 (a 3a. Ollmpica). 
10a. Olimpica (v.1-3). Enquanto inscrição, objeto perene, o poema se torna instrumento de re-conhecimento da vitória, açăo que, em grego, se expressa pelo verbo anagignósko: ler. (Re)conhecimento e leitura se (con)fundem na mesma ação perenizadora da efeméride. Ler o poema é pois reconhecer a efeméride na açăo de conhecer de novo, de conhecer bem, de conhecer com certeza e de prestar reconhecimento, o que se torna possível porque a efeméride factual foi elevada à categoria do que está escrito ("tôn Olympionfkan...gégraptai"; OI X, 1-3).

A possibilidade da anágnosis é que determina, pois, a legibilidade do texto de Pindaro fora do contexto da festa. Ele deixa assim de ter um sentido univoco para se abrir a novas experiências $\theta$ compreensóes. Aristóteles já observava, com relaçăo à tragédia, que mesmo através da mera leitura uma peça poderia produzir seus efeitos ${ }^{5}$. O mesmo diria das odes epinf́cias de Pindaro. Sem dúvida năo se trata de efeito idêntico ao experimentado pelos participantes da festa, mas de efeitos igualmente legfimos $\theta$ pressupostos pelos poemas. Diante do texto perene, a experiéncia estética e a compreensão dependem sempre de um esforço de atualização de virtualidades, numa leitura entendida como re-conhecimento.

É o que me proponho fazer, elegendo como objeto as três primeiras Olimpicas. A escolha baseia-se no fato de todas elas terem sido compostas no mesmo perfodo - o ano de 476 a.C. - e dedicadas a dois príncipes da Sicflia, Hierăo de Siracusa e Terăo de Agrigento. A data $\theta$ o local săo sem dúvida importantes, uma vez que a viagem à Siclia representa a afirmaçáo da fama do poeta $\theta$ o início de seu perlodo mais criativo (os estudiosos costumam situá-lo entre 480 e 460). De fato ele conta 42 anos, se aceitarmos a data de 518 para seu nascimento ${ }^{6}$, ou seja, encontra-se na akmé, no infcio daquele perfodo da vida em que, segundo Sólon, se estende o espirito em seu direito e nunca para afazeres inúteis 6 conduzido?.

A produçăo de Pindaro, nessa fase, reflete mudanças favoráveis. Como observa J. Finley Jr., "esta visita a um novo mundo completa sua emancipaçăo"8 Emancipaçăo em termos de pensamento, de técnica $\theta$ de arte: "emancipaçăo de todo esquema fixo $\theta$ aceitação de si mesmo"g, quando o poeta atinge sua maturidade. Todo esse processo vem a par e, em certa medida, em decorréncia da fama, o que o leva a refletir com mais profundidade sobre o sentido de sua poesia e de sua missáo. Crelo que $\theta$ a partir de entăo que a consciência da perenidade de sua produçăo irá crescer para o autor. Năo se trata mais apenas de cantar uma vitória $\theta$ um vencedor, mas de transmitir, através do canto, uma diangella que $\theta$ fruto de sua própria reflexáo sobre as relaçoes da poesla com os sucessos attéticos, que por sua vez se relacionam com os antigos sucessos heróicos e com os sucessos divinos. O esquema formál do epinicio, que alla ao

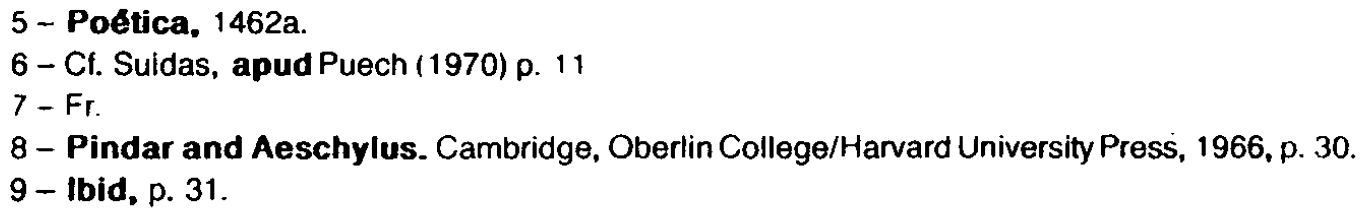


louvor do atteta a lembrança das antigas gestas herbicas e divinas, deixaria de ser uma imposiçáo e transformar-se-la, pela mediaçăo do poeta que canta. É o próprio estatuto do poeta que se póe assim em jogo, em suas relaçóes com o mundo superior de deuses $\theta$ heróis, com a comunidade a quem se dirige 0 canto e com a posteridade a que ele se trans-mite.

$\mathrm{Na}$ análise do corpus escolhido procurarei ressaltar que idéia Pindaro tem do proprio trabalho nesse momento crucial de sua carreira, sob a perspectativa dessas múltiplas relaçóes. Análise é portanto um termo inadequado. A análise deve funcionar apenas como instrumento da anágnosis, leitura/ reconhecimento em que se busca atingir 0 sentido do texto.

\section{A água 0 o ouro: o poeta como mediador}

Julgo que a característica comum mais marcante das três odes de que me ocupo está no fato de, nelas, a reflexăo sobre o sentido da função do poeta e do poema colocar-se em pé de igualdade, em termos de importância, como o canto da vitória e do motivo mitico com ela relacionado. Em termos gerais, as referências à natureza e função do canto năo deixam de estar presentes, ainda quando de modo menos explícito, em outras produçర̋es. Mas nas três primeiras Ollmpicas - como já se observou, escritas em perfodos temporalmente próximos e em uma mesma situaçăo - o aspecto se torna especialmente relevante.

J. Duchemin ${ }^{10}$ levantou farta documentação, retirada dos próprios textos, relativa à concepção da atividade poética presente nas obras de Pindaro. Sem descer a detaIhes, reteria o dado de que ao poeta cabe uma missão de transmitir aos demais homens uma determinada sabedoria que ele proprio recebe dos deuses. Abstrafdas particularidades, essa visăo da poesia não contradiz o senso comum então vigente. O poeta ê um privilegiado, cuja atividade se coloca como mediadora entre duas esferas do cosmo, a divina $\theta$ a humana, ou a mftica $\theta$ a histórica.

Nos epinícios de Pindaro, todavia, o sentido superior da poesia assume maior briIho, dado que nåo julgaria fortuito, mas na dependência do contexto determinado pela comemoraçăo da vitória. Mais que nunca cabe ao poeta exercer sua função mediadora, fazendo a vitória transcender o plano do factual para inscrever-se no conjunto maior de um cosmo em que as partes se relacionam: Assim, a força do fato concreto toma imperioso fazer mais nitido e brilhante o sentido da transcendência. Todos os elementos que, associados, compóem a efeméride da vitória nos jogos, devem ser dirigidos nesse sentido: a vitória enquanto feito; o vitorioso enquanto seu agente; o espaço da prova como cenário e palco do evento; a cidade, a raça, a famflia $\theta$ a festa do vitorioso enquanto prolongamentos da açăo gloriosa. Todos esses dados, pertencentes ao domínio do humano, sáo arrancados dele, num primeiro momento, pela grandeza reconhecida socialmente à própria açăo perpetrada, acontecida no espaço sagrado de um templofamoso, mas apenas definitivamente pelo canto da vitória, que a insere no domínio dos

10 - Pindare, poète et prophèta. Paris, Belles Lettes, 1955. 
feitos gloriosos de deuses e herois. O sentido da inspiraçăo que move o poeta poderia ser entendido como um movimento capaz de revelar a transcendéncia dos elementos efêmeros que se relacionam com o evento, cabendo-lhe interpretar esses elementos em face de um nivel de realidade superior e atemporal.

Os famosos versos que abrem a 1a Olimpica colocam-se, desse modo, como um verdadeiro programa:

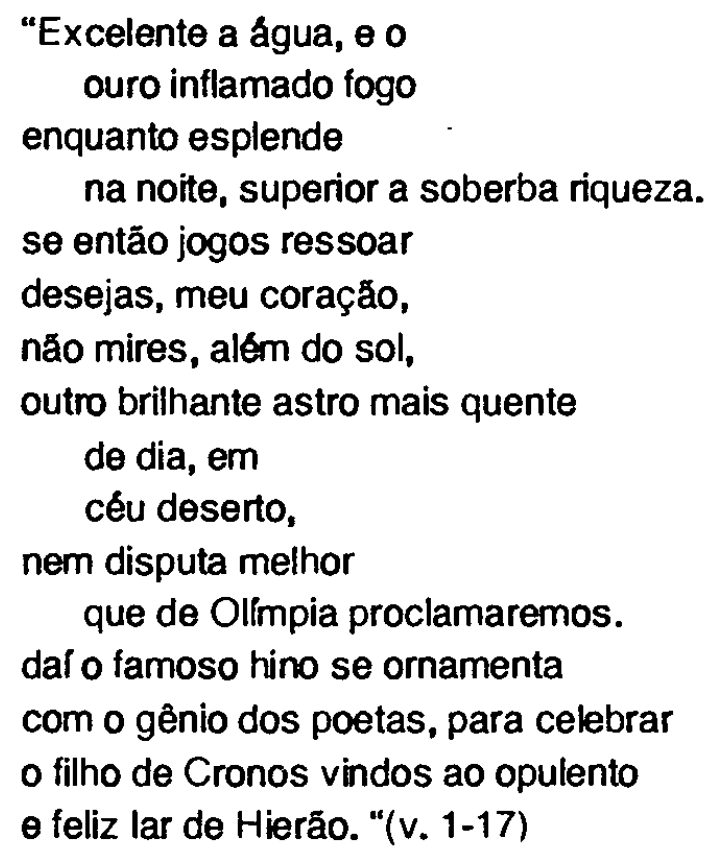

Os problemas de interpretação que essa abertura levanta se devem, em grande parte, ao fato de que não se procura ver todo o trecho como uma unidade, bem marcada, aliás, por conformar uma estrofe, que por sua vez se liga à antístrofe e ao epodo seguintes como sub-unidade de um conjunto tripartido. O relativo hós, que aparece no primeiro verso da ant'strofe, ao mesmo tempo que ata as duas partes, marca sua separação: a alusão a Hierăo ( $v .17)$ constitui o gancho que fornece ao poeta o tema da unidade seguinte, dedicada a referéncias ao tirano e a sua vitória; do mesmo modo, a alusão a Siracusa, abrindo o epodo (v. 35), dá margem à introduçăo do mito de Pélops e Tântalo. Ora, se é relativamente fácil determinar na ant'strofe e no epodo um percurso que vai de Hierăo à vitória e de Siracusa (e seu tirano) ao mito, respectivamente, cabe indagar de que trata a estrofe de abertura, que movimento se registra nela.

Em princlpio, escolheria a resposta mais simples, afimando que se trata de un a unidade que val do áriston à Hiéronos hestian. Assim, o mesmo movimento que ata Hieråo à vitória (hós/krátei), na ant́strofe, e Siracusa (e seu tirano) aom ito (Sirakosion...basilea/mythoi), no epodo, liga o "excelente" ao lar de Hierăo" na estrofe. Uma primeira observação, portanto, relativa às três partes, $\theta$ que Hierăo é o grande elo que garante a unidade do primeiro movimento do poema. Se isso é verdade, poderíamos, em seguida, apenas para efeito de análise, abstrair da presença de Hierão (já que ela, 
sendo jconstante, năo poderia servir de critério para o estabelecimento do conteúdo principal e particular de cada trecho), delimitando mais estritamente que o objeto da antéstrofe é a vitória e o do epodo a cidade de Siracusa, colónia do lidio Pélops, ao qual diz respeito o mito. Na mesma linha de raciocínio, caberia então voltar ao áriston que abre o poema, para investigar a que se refere.

Mantendo temporariamente o processo analftico, creio conveniente separar a estrofe em tres partes, sintática e semanticamente bem delineadas: os versos 1-4; os versos 5-13; $\theta$ os versos 14-17. Parece evidente que a unidade sintática aberta no verso 1 se estende até o 4, introduzindo o verso seguinte nova unidade de pensamento dependente do condicional el cujas conseqüências se desdobram nas posiçర̋es coordenadas introduzidas por mekéti (v.7) e mede (v.11). Já o advérbio de procedência hothen (v.14) introduz nova unidade, desenvolvida a partir da referencia anterior a Olimpla (v.11). Assim, constata-se um esquema bem arquitetado de desenvolvimento de pensamento em que as unidades se distinguem sem se isolar. Especialmente as duas últimas partes llustram um processo peculiar da poesia de Pindaro, quando uma referência aparenternente fortuita serve de gancho para o desenvolvimento da unidade seguinte" ${ }^{11}$.

Ora, o problema maior permanece com relação ao sentido dos versos $1-4$, que admitimos ser uma primeira unidade no corpo da estrofe. Năo haveria necessidade, nesse caso, de apelar para dados exteriores ao texto, como faz o escoliasta ao sugerir que a alusăo à água se explicaria em face do postulado de Tales que afimou ser esta princíplo de todos as coisas; muito menos seria desejável ler o verso diffcil acrescentando o que nele năo está, como fazem alguns tradutores ${ }^{12}$. Por isso, proponho uma leittura o mais possivel fiel à letra do poema:

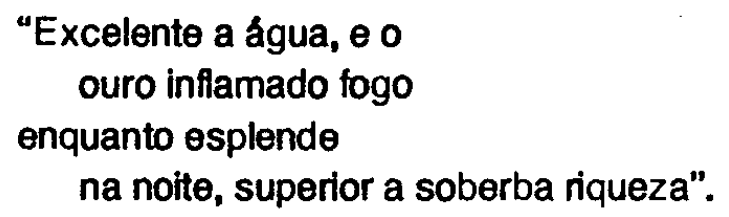

De fato, năo me parece que Pindaro se referia ao "maior dos bens" nem a um primeiro elemento a que se oporiam outros. $O$ áriston, nesse caso, significaria mais bem o excelente, estando as duas proposiçces nominais em relaçăo bem estabelecida pelas partfculas mén...de, que permitiriam o entendimento: (por um lado) a água (é) excelente, $\theta$ (por outro lado) 0 ouro $(\theta)$ fogo inflado. Esse paralelismo das duas proposiçoes toma, por sua vez, dispensável o entendimento de háte como elemento introdutor de uma comparaçáo (o ouro é inflamado como fogo; ou o ouro é como fogo inflamado), o

11 - Crelo que essa tócnica é das mais pecullares em Pindaro, servindo para desenvolver náo apenas unidades menores, como no caso acima aludido, mas também para conformar a arquitetura do poema como um todo. É através desse processo que mito, vitória, jogos, etc., se sucedem e se relacionam sem cortes abruptos, orientando um certo sentido do texto. cit.)

12 - C.., por exemplo, Puech: "Le premier des biens est l'eau" (p. 26 de ediçăo de Píndaro, op. 
que levaria a um sentido bem determinado: o ouro (é) fogo inflamado énquanto (já que, posto que, porque) esplende na noite superiormente à soberba riqueza. Com efeito, o advérbio éxokha, derivado de éxokhos (eminente, superior, excelente, assinalado), composto por sua vez de ex e ékhein, em que o elemento ex realça o sentido de algo que se destaca, aproxima o ouro da água, lá que o conceito de excelente (em latim ex-cellens) é comum à esfera semântica de éxokhos $\theta$ de áristos. Desse modo, os versos em questão tratariam da excelência da água e do ouro, ou seja, o cerne de seu sentido repousa no conceito de excelencia.

Mas a que remeteria esse sentido? Tal resposta só poderá ser dada se, reparando a fragmentaçăo temporária a que submetemos o texto, pusermos agora em relaçáo os versos em pauta com o resto da estrofe. À bipartiçăo deles (água/ouro) corresponde uma bipartiçăo da proposição seguinte, expressa de forma negativa: nada mais quente (ou vivificante) que o sol; nem melhor que as disputas de Olimpia. Vertido para forma positiva, surgiria assim o esquema sol/disputas ollmpicas, que corresponderia a água/ouro. Por um sistema de transposiçăo, seria lícito entender que a qualidade de áristos se aplicaria também àquele par, através da mediação do poeta que canta.

A ordenação parece natural: o poeta canta a excelência da água $\theta$ do ouro, pois 6 o que ele de fato faz nos quatro primeiros versos. Mas se deseja cantar disputas atléticas, então năo deve buscar nada além do sol ou dos jogos de Olimpia, pois esses são assuntos táo dignos de ser cantados quanto a água e o ouro. Assim, na correlaçăo das duas seqüências, o que se pбe em causa e a exceléncia do objeto do canto, devendo os versos 5-6 ser entendidos como nodais, ao colocar em jogo o desejo de cantar (garyen éldeai), 0 intimo do poeta (phiton êtor) $\theta$ os jogos (eathla). Garyen $\theta$ étor sáo al elementos-chave pois instauram o caráter do canto. Em primeiro lugar, $\theta$ o étor do poeta que canta ou que impulsiona ao desejo de cantar. Já o verbo utilizado, embora possa, em sentido especializado e determinado pelo contexto, ser entendido como cantar, comporta acepçర̋es mais abrangentes, relativas à emissåo de som pela fala: fazer ressoar, fazer ouvir, dizer. Assim, o desejo a que o impele o coração ê bem mais de fazer ressoar, pela fala, os áethla, de dizer as disputas attéticas, de transpo-las do plano factual para o verbal $\theta$, assim, celebr(iz)á-las.

$O$ entendimento da relação dos versos 1-12 com os seguintes exige o mesmo esforço de penetraçăo no texto. Como já observel, 6 Olimpia que dá ocasião à passagem de uma esfera à outra. De Ollmpia vem a ser (lança-se em tomo, veste-se, ornamenta-se) o hino, pelos engenhos dos sábios (metfessi sophon). Este trecho se abre pois, como 0 anterior, com uma consideraçáo relativa ao canto $\theta$ ao poeta, chamado honrosamente de sophos. A expressåo métis sophon $\theta$ quase redundante, podendo ser entendida como sabedoria dos sáblos. Esse elemento de sapiencia é que confirmará e determinará a inelutabilidade de que o objeto do canto seja aquilo que $\theta$ áriston, como o săo a água e o ouro, o sole os jogos de Olimpia. Dessa mesma condlçáo participam aqueles que cantam o filho de Cronos na casa de Hieráo - o que o próprío Pindaro faz no próprio poema. Se antes tínhamos como objeto do canto entidades genéricas - água/ouro; sol/jogos ollmpicos - agora se desce à nomeaçáo particulart 
zade: Zeus/Hierão, ou seja, por toda série de transposiçőes a que dá lugar a própria estrutura da estrofe, a Zeus e a Hieråo cabe na noite superiormente à opulenta riqueza. A excelência da água é inerente a ela, mas a excelência do ouro se impõe apenas enquanto a outros objetos (éx-okha). A preeminência do sol no céu deserto é por igual absoluta, mas a dos jogos olimpicos relativa a outros jogos. Embora o poeta, ao reforir-se ao sol, fale de outros astros, ajunta que ele se faz ver no céu deserto, ou seja, é único durante o dia. Finalmente a grandeza superior de Zeus é que comunica à casa de Hieráo um caráter assinalado, enquanto para ela acorrem os poetas. Ora, essa eminência relativa de que gozam o ouro, os jogos ollmpicos e Hierão, como primeiros entre pares, so se efetiva na medida em que, através dos hinos dos poetas, participam eles da eminência absoluta da água, do sol e de Zeus. Deixa pois de ser necessário admitir que a água, o ouro e o sol sejam metáforas, para se investirem da qualidade de seu ser, do qual se transmite a condição de excelente para outras esferas postas em relação com eles pela ode.

\section{Assaltar as colunas de Héracles: a função do mito no canto}

A sugestiva retomada das imagens da água e do ouro na 3a. Olimpica repete e referenda a interpretação sugerida, com base num esquema bipartido. Diz o poeta:

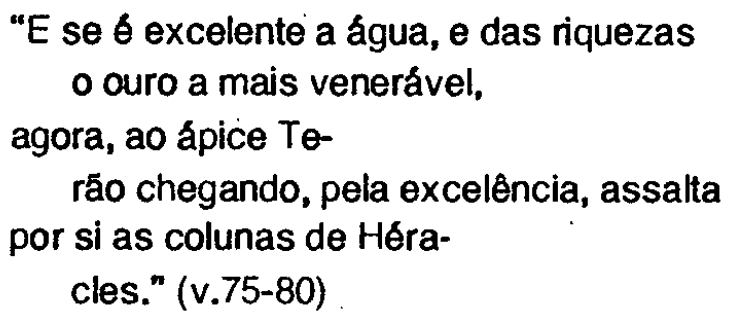

Parece-me que, dividida em duas metades, separadas pelo termo agora (nyn), colocam-se de um lado ja água e o ouro, e de ouro Terão. O paralelismo é acentuado, pois Terão atinge o ápice pela excelência (aretaîsi, ou seja, participa ele de algum modo do aristeyein que é próprio da água. Esta, por natureza, é excelente, não podendo a tradução portuguesa do verbo grego (aristeyei) dar conta exata de que, como sujeito da oraçăo, é a própria água que exerce ativamente a funçăo de ser excelente; já Terăo atinge a excelência (ou ápice) por meio das virtudes (aretaîsi), o que o dativo instrumental deixa claro. Por outro lado, esse caráter de excelência que pertencia à água, Terăo o alcança igualando-se a Héracles, repetindo a ação eminente do herói que fala confirmado nela pela propria apoteose, lembrada nos versos 64-65. Nesse caso fica clara a possibilidade de transmissáo da excelência da água para o ouro, como de Héracles para Terăo.

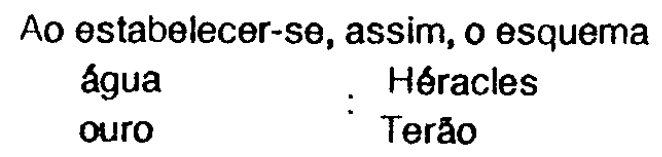


instaura-se novo problema de interpretação, relativo à natureza de Héracles. Acima, ele ocupa o posto que, na 1a. Olimpica, cabe a Zeus, ou seja, trata-se do herói divinizado. Mas enquanto heroi e mortal é de supor-se que, em algum momento, estivera na posiçáo de Terăo, trocando de posto em virtude de sua divinizaçăo. Desse modo, o sentido da utilizaçăo do mito de Héracles na 3a Olimpica se deixa perceber, em razáo do movimento de transcendéncia que eleva o herói ao patamar dos deuses. Ora, se 6 verdade que a função do hino é alçar a efeméride da vitória à transcendéncia das açőes mfticas, pelo processo de fazer participar o vencedor da excelência divina, seria igualmente verdadeiro que o uso do mito pelo poeta deveria cumprir a funçăo de tomar praticamente viável esse movimento:

Năo creio, de fato, que a presença do mito possa ser considerada conseqüência da imposiçăo de um modelo fixo, nem muito menos que tenha uma funçăo meramente ilustrativa $\theta$ apenas sirva de pretexto para introdução de outros conteúdos, dada a importáncia $\theta$ extensăo dom ito no corpo do poema. O mito é parte integrante da ode $\theta$ só está nela porque the cabe uma determinada funçáo. Se o louvor do vitorioso é indispensável, pois o poema se fez para isso, $\theta$ o louvor dos deuses $\theta$ compreensivel, já que nos jogos existe um elemento marcante de sacralidade, por que os mitos herólcos? Năo parece táo evidente, como nos casos anteriores, sua presençăo no poema $\theta$, raciocinando em extremos, năo seriam eles dispensáveis? Em outros termos, năo poderia o poeta transmitir sua mensagem, não poderia o poeta surtir seus efeltos sem o uso do mito?

Qualquer pessoa com um minimo de conhecimento lda produçăo de Píndaro decerto responderia que não. Mas não basta. É preciso de novo perguntar por que não. Parece que a abertura da 2a. Olimpica pode fornecer plstas para a resposta. Em primeiro lugar, porque considera os herois como objeto do canto em pe de igualdade com deuses $\theta$ vitoriosos:

"Reis da lira - hinos, que deus, que herol, que homem celebraremos?" (v. 1-3)

As escolhas, determinadas pela situaçăo, săo significativas, pols continua o poeta:

"por certo Pisa é de Zeus; às Olimpladas erigiu Héracles, primicias de combate;

e a Terâo, da quadriga, pela vitória,

É mister celebrar..." (v.5-10)

A justificativa da escolha do objeto do canto impoe-se assim a partir de certos critérios: Zeus, por ser senhor de Pisa; Héracles, por ter Insttuido os jogos; Teráo, pela vitória recente. Apesar de ser o derradeiro, $\theta$ Terăo, na verdade, que provoca o canto; a ele dedicado. Hierarquicamente dependente de Zeus e de Heracles, estes contudo de- 
pendem da vitória daquele para serem cantados. A vitória, em si, dispensaria os outros niveis, mas se perderia na fatuidade de um acontecimento particular. De novo se evidencia que a missão do poeta $e$ justamente fazer a vitória transcender seus limites ao relacioná-la com deuses $\theta$ heróis: keledein (v. 3) e gegonein (v. 10) significam propriamente fazer ressoar (ecoar), e dal, celebrar e celebrizar. Quem celebraremos? pergunta o poeta, colocando de antemão que deve ser um deus, um herói e um homem. Ele considera assim justo tomar como implicito que deve cantar os três. $O$ que, na 1a. Olímpica, $\mathbf{e}$ objeto de longa reflexăo, aqui já se coloca como programa da ode, en certa medida considerando o que fol dito no poema anterior. $O$ que se deve decidir năo $\theta$ pois propriamente o que cantar, mas qual deus, qual herói $\theta$ qual homem ("tina theón, tín'héroa, tina d'ândra").

A posiçăo do herói nessa enumeraçăo coloca-o como intemediário entre o deus o o homem a serem escolhidos. Da evidéncia de que Zeus deve ser cantado, pois Pisa é de Zeus, chega-se à evidéncia de que Terão também merece sê-lo, pelo sucesso alcançado, através da mediaçẫo de Héracles que institulu, no espaço de Zeus, os jogos em que Teráo se distinguiu. É através dos jogos que a fama de Teráo se alia à glória de Zeus. Mas isso so é possivel porque Héracles, um dia, fundou as Olimpladas, as quais cumprem a funçăo de viabilizar esse movimento dos mortais até o senhor de Ollmpia, Isto 6 , do efêmero ao perene. Como se afirma no trecho antes citado da 3a. Olimpica, $\theta$ através de Héracles que Teráo atinge o ápice.

É significativo que, na 2a. Olimpica, o mito de Héracles náo seja desenvolvido, como poderia ser de se, esperar. A partir do gancho constituido pela referência aos patéres do vitorioso, ainda na primeira estrofe, o poeta escolhe ter como esqueleto a determinar o movimento da ode a história dos antepassados míticos do rel, de Cadmo a Tersandro. Sendo uma estirpe marcada pelo infortúnio (Semele, Ino, Laio, Édipo, Polintce), o tema do sofrimento pode ser desenvolvido, centrado na consideraçăo das correntes que

"...outras em outro tempo

tanto com felicidade quanto com sofrimento para os homens verm" (v. 63-65).

Tersandro, sobrevivendo a Polinice, recebeu sem dúvida a primeira sorte, honrado como vitorioso nos jogo como na guerra (cf. v. 77-80). É ele pois que se coloca como modelo mais próximo da sorte de Terăo. De Cadmo e de suas filhas divinizadas o poeta percorre o trajeto até Tersandro, no qual a ligaçăo familiar com os Adrástidas $\theta$, conseqüentemente com Teråo, se manifesta de modo especular. Assim, a mediaçăo do elemento henbico permite o movimento que vai de Zeus (a quem cabe inclusive um papel concreto no ipisódio de Sêmele) a Teráo.

Basicamente, portanto, os mitos ligados à familla de Teráo cumprem o mesmo papel de Héracles na abertura. O fato de Héracles ser flho de Zeus, ou seja, de estar ligado a divindade por liames de parentesco, sem deixar de ser mortal, toma possivel o recurso da genealogia mfíca. Em Héracles se resume a funçăo atribulda a longa série 
de geraçర̋es apresentadas. Ele soztnho é capaz de efetivar a ligaçăo entre Zeus o os homens, ele sozinho conheceu, na vida, ondas sucessivas de felicidade e de infortúnio. Năo creio que, referindo-se a Héracles de inicio, o poeta tenha mudado de idéla a seguir, simplesmente abandonando seu mito por outros. O procedimento, pelo contrário, parece-me justamente confirmar que, mais que uma ou outra lenda, o poeta vê no mito heróico uma funçáo de intermediaçáo.

Isso não significa que as características particulares de cada vitória não orientem a escolha do mito. Săo as ligaçóes de Pélops com Siracusa que atam sua historia a Hierăo, como săo as ligaçő́es de Terăo com Tersandro que justificam a genealogia mfíca. A 3a. Olimpica, contudo, oferece exemplo diverso, pois năo há ligaçăo de famflia nem de pátria entre Terăo e Héracles. Este se introduz no poema em virtude das coroas que trazem os vitoriosos, as quais remetem para a lenda de que Héracles é que teria trazido para Olimpia a ârvore de cujas folhas eram feitas. Mas já vimos como, através de sua dupla natureza, Héracles serve de mediador entre os homens e om undo divino. Talvez justamente por isso seja ele tăo caro a Plndaro, que considera

"mudo aquele homem que a Héracles a boca năo consagrar" (Pit, IX, 151-152),

pois é ele "aristomákhos" (Pit, X, 4), excelente guerreiro ou, se quisermos, o guerreiro por excelência. Embora a predileçåo por Héracles possa ser rastreada em fatos dlversos, como nas relaçర̋es do mítico herói com Tebas, pátria do poeta, creio que deva ser preferencialmente explicada em virtude da excelência que nele se realiza de modo particularmente elevado, fazendo-o o herói por excelencia capaz de cumprir a funçăo de relacionar o mundo divino com o mundo humano. Nesse sentido, o herol que de fato mais merece ser cantado é sempre Héracles. É a função de Héracles que o poeta pede sempre aos demais herois que repitam, ao induzi-los em seus cantos de vitória.

\section{Cantar um estrangeiro: o poeta 00 rel}

Se pois a vitória dita no poema 6 transcendida, pela própria razáo de passar à categoria do dito (e do escrito), isso se faz através do mito. O poeta, que mediatiza a festa com seu canto, usa o mito como mediador entre a vitória factual e a vitória celebr(iz)ada. Isso quer dizer que, ao eleger o mito, o poeta tem consciéncla de que poderá extrair dele um certo sentido, que o mito suporta uma determinada leitura que rege sua escoIha. Noutros termos, ao utilizar o mito o poeta age com discemimento.

Esse discemtmento atua năo apenas com relaçăo à elelçăo de algum entrecho. mas também com respelto ao que realçar nele. Náo é a narratlva ou a figura mftica, em sl, que interessa, mas o efelto que se pretende tirar delas. Dal que, lançando máo do mito, o poeta demonstre ter consciéncia critica com relaçấo ao mesmo. Isso parece evidente na referéncia ás duas versóes da lenda de Tántalo, na 1 a. Olfmpica.

"Decerto há multas maravilhas, $\theta$ quiçá também a dos mortais 
fala vá além do verdadeiro discurso:

adornados com mentiras coloridas

enganam os mitos" (v. 43-47).

Ora, o importante, nesse caso, năo $\theta$ apenas a constataçăo de que os mitos podem ser enganadores, mas a de que podem sé-lo em virtude de uma certa arte: tanto o verbo daidállein (que traduzi por adornar) tem sentido francamente positivo, indicando um trabalho finamente elaborado, quando $o$ adjetivo poiknlos (colorido) sugere uma especial riqueza de matéria. É na brotón fátis (a dos mortais fala) que se enralza o desvio de tais enganadoras histórias, sempre que ela ultrapassa 0 alathe logon (verdadeiro discurso). Da distinçăo entre esses dois extremos, a fátis e o logos, brota o discernimento, baseado no testemunho dos tempos futuros e no pressuposto de que năo devem ser atribuldas aos deuses açoes indignas:

"Mas a Graça, que tudo constrói de doce para os mortais, trazendo hon-

ra, também o incrivel maquina crivel

ser multas vezes;

mas os dia vindouros

testemunhas mui sábias.

É ao homem conveniente dizer

sobre deuses belezas; me-

nor pols a culpa." (v. 48-57)

Esse princlpio parece-me, ao contrário do que afirma Puech ${ }^{14}$, aplicar-se em geral a deuses $\theta$ heróis. O próprio fato de comumente Pindaro silenciar ou náo relevar as açoes indignas dos heróls demonstra sua aplicaçăo. Náo seria de esperar que ele refutasse cada passo considerado chocante, como faz aqui, através de consideraçరes tobricas, pols năo se deve esperar uma perfeita analogia entre todas as odes. Na 1a. Olfmpica, essa $\theta$ mais uma prova, o poeta reflete explicttamente sobre o sentido de sua missão $\theta$ sobre os critérios que regulam sua attvidade. $O$ trecho citado deve assim ser entendido como um programa poético cuja aplicaçáo pode ser detectada em outros poemas.

Mas o que regula a aplicaçăo de tal programa $\theta$, de fato, o efeilto que se pretende tirar do mito. Um dado chocante, como o parricldio $\theta$ o fraticfdio referídos na 2a. Olimpica pode dar margem à transmissão de verdades elevadas. Tudo depende da intençăo da obra $\theta$ da funçăo que o mito tem nela. No últtmo caso, interessa ressaltar a variedade de sortes, o caráter imprevisivel da Moira que traz felicidades e desgraças (v. 65-69), o que dá margem à consideraçáo da diversidade de destinos do homem nesta vida $\theta$ após ela (v. 110-136).

O interessante, entretanto, $\theta$ que a fala mentirosa se deve também à Graça 14 - Op. clt, p. 28, nota. 
(kháris). Jacqueline Duchemin, no |livro já citado, estudou bem a importância que têm as khárites como divindades a quem, como às Musas e às Horas, o poeta deve sua inspiraçăo. Em princlpio, portanto, haveria duas espécies de khárls, cabendo ao poeta discemir entre elas. Ora, no mesmo texto o autor usa o termo kháris ao falar da vitória de Ferênico, em passagem já citada, multo rica de sentido:

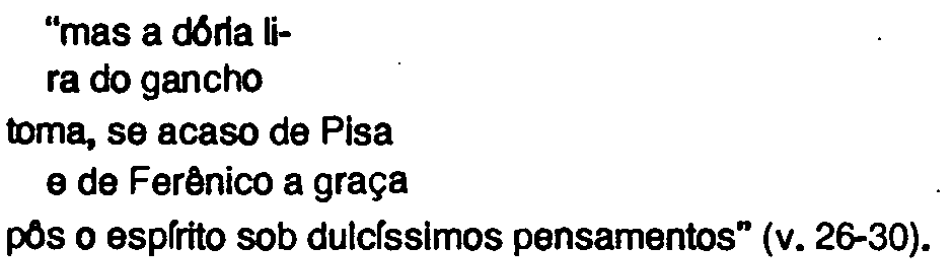

É essa kháris de Pisa e de Ferênico que dá origem ao poèma, uma kháris sem dúvida envolta pela verdade observável da vitória. Em face da lenda mentirosa do banquete dos deuses se coloca a certeza da vitória, detalhadamente descrita (cf. v. 31-33). A kháris que irradia da vitória é assim autêntica, tanto que na 2a. Olimpica săo as próprias Khárites que levam em comum a coroa que recompensa os vencedores ( $v$. 90-92).

Não creio que se deva entender as duas referências à kháris como diferentes ${ }^{15}$. O que parece existir é antes a consciência da necessidade de discernimento da kháris, a partir da conformidade da vitória com o mito: assim como a vitória é verdadeira, 0 mito deve sê-lo; assim como os dias futuros daráo testemunho da vitória, é preciso testar o mito da perspectiva deles. O testemunho deles 6 , com efeito, sophótatos. Năo se pode esquecer que antes o poeta fora chamado de sábio e sua arte de "sabedoria dos sábios" (v. 15). O testemunho do futuro $\theta 0$ dos poetas têm assim alguma relaçăo, ao provocar o discemimento da kharis, separando nela o verdadeiro daquilo que năo passa de mentira devido à inveja (cf. v. 47-75). Ao declarar que falará do filho de Tântalo contra (antfa) o que disseram os antecessores (v. 58-59), o poeta quer declarar que faltou àqueles discemimento ao tomarem o mito, ou, noutros termos, faltou-lhes kharis. Discemimento que Pindaro busca justamente na kharis que flui de Pisa $\theta$ da vitória de Ferênico, a qual the dá a medida da elevaçáo que náo deve faltar no relato mítico. Ou seja, é na comparaçăo com deuses e herós que o vitorioso $\theta$ confirmado em sua grandeza, mas a grandeza divina e heróica só pode ser percebida a partir da consideraçáo da grandeza do vitorioso. A excelêncla do sucesso da vitória, transcendida no logos do poeta, revela a açăo divina e se faz critério de discemimento.

Esse mesmo movimento que leva do vitorioso aos herols e deuses e destes àquele se repete na relação entre o poeta e o objeto de seu canto. Ao pretender dizer o mito contra os anteriores, PIndaro sublinha, com certeza, que é dono de uma kharis particular. Creio que se poderia transpor a relaçáo antes descrtta, afịmando-se que ao

15 - Puech traduz a palavra, no caso de Pisa e de Ferénico, por honneur, no outro, por G6nie, em nota, explica suas razóes. Já Malhadas prefere brilho e Giraça, respectivamente. Preferi verter, nos dols casos, kháris por graça. 
mesmo tempo que é o poeta que toma a vitória algo de grandioso, é a vitória que dá grandiosidade ao poeta. A kharis do poeta flui da kharis da vitória. Não há como separar as duas sortes.

Desse modo, a arte do poeta se envolve com a grandeza daqueles que canta. Nesse sentido é que se poderia atribuir à obra de Plndaro o qualificativo de aristocratica. Decerto ela o é, năo no sentido enviesado de que se póe a serviço de uma aristocracia enquanto classe social, mas no sentido de que busca o áriston. Ora, a aristela sem dúvida brilha na performance dos príncipes poderosos que realizam feitos semeIhantes aos dos heróis e deuses no estádio de Olimpia. Essa aristela se expande $\theta$ cobre igualmente de brilho as cortes, as cidades $\theta$ as famlias de tais príncipes. A mesma aristela explende nos mitos que o poeta elege $\theta$, finalmente, no próprio canto que faz brilhar a festa. $O$ que poderia pois ser entendido como o caráter aristocrático da produçáo de Pindaro seria esse movimento de elevação e de brilho que toma conta de tudo o que passa pela mediatizaçăo de sua fala poética. Năo haveria porque estranhar que, dedicando-se quase que totalmente ao louvor da aristocracia, pois era dela que provinham as mais brilhantes personagens de seu tempo, ele também se referia à democracia Atenas como brilhante, celebrada pelos poetas e cidade divina (Dit, fr. 5). Onde quer que brilhe a aristela, ainda quando năo nos limites de uma classe aristocrática, para al se volta seu canto.

Enquanto se alia, pois, aos áristoi, o poeta, de um certo modo, garante o brilho de sua obra e de sua fama. Dirigindo-se a Hierão, ele conclui, na 1a. Olimpica

$\because . . . A$ mim pois

a Musa valorosissi-

ma flecha, em auxlio, provê:

para uns, outros grandes; o su-

premo se eleva

para reis. Jamais in-

vestigues além.

E a ti o cimo nes-

to tempo calcar,

Q a mim pois com vencedores

estar, famoso pelo gênio entre os he-

lenos sendo em tudo." (v. 178-188)

O que se efetiva, dessa forma, o enlace do destino do poeta ao do rei. De fato, a metáfora das flechas que a Musa prove ao poeta só se esclarece na sua relaçáo com a eminencia da realeza. O verso 181, de leltura penosa e polêmica, e o essencial nesse caso. Ele $\theta$ que efetiva a ligaçăo entre a Musa/o poeta $\theta$ a grandeza dos rels. Dentre outras sugestros, de outros tradutores, prefiro o entendimento mais próximo da letra, ainda que mais nebuloso: "para uns, outros grandes", ou seja, para grandes, outros 
grandes. De fato, o paralelismo dos pronomes sugere isso ${ }^{16}$. Ao mesmo tempo, a gama semântica de mégas (grande, alto, elevado

tante) permite a aproximaçăo com o adjetivo karterós (forte, potente, valoroso, veomente, impetuoso), aplicado à flecha que a Musa entrega ao poeta, e com o adjetivo substantivado éskhatos (último, extremo, o mais alto, o maior), que designa a grandeza que se eleva para os reis. Assim, $\theta$ através das qualidades de forte, potente, valoroso, veemente, grande $\theta$ alto que o poeta se aproxima do rei: para um grande, outro grande; para um forte, outro forte; para um alto, outro alto.

Se o grau supremo de todas essas qualidades se eleva para os reis, o poeta 0 acompanha, pois só um grande pode cantar outro grande. Além dessa altura, năo se deve investigar. Assim, o rel e o poeta colocam-se no cimo do possivel ao homem. $O$ estabelecimento dessa relaçăo e o fato de o poeta associar-se ao rei tem conseqüências para a fama. O poeta náo é da mesma natureza que o rei, mas se torna o outro dele pela ação de estar com ele.

Ora, o que traduzi por estar com se diz, no poema, homileín, isto é, entreter-se com, ter familiaridade com, encontrar-se junto com, falar com, discorrer com; combater com; aplicar-se a, ocupar-se de. Parece-me que a idéla básica, subjacente a todos esses significados, seria a da existência de uma relaçăo interpessoal, o que se confirma nos usos do mesmo termo na esfera das relaçбes conjugais e de comércio. No homileín (ter relaçăo), se associa o poeta ao rei. Ora, hómilos, de que deriva o verbo, significa multidăo. Assim, a açăo de homileín poderia ser entendida como uma sorte de eleiçăo: na multidăo existe uma relaçăo compacta e difusa que so atinge o estar com através de um processo de seleção. Na multidão de soldados, por exemplo, o combater com (homilein) se efetiva no enfrentamento de dois que, na multidăo, se escolhem um ao outro.

Um processo análogo se dá quando a um grande corresponde outro grande, na multidăo dos homens em geral, o que se efetiva em grau supremo no enfretamento entre rei e poeta. Existiria um elemento de atração dos semelhantes nessa relaçăo, aliado à constataçăo da diterença. O rel é um (állos) a què corresponde um outro (állos) constituido pelo poeta. Esse caráter do outro parece-me bem marcado nos epinictos de Píndaro, em geral, pela insistência com que lembra ele sua condiçăo de xénos (estrangeiro). Vimos como; na 1a. Olimpica os poetas acorrem à casa de Hleráo, o que supbe que estáo nela como estranhos (v. 16-17); logo no início da 2a. Olímpica, Terăo e elogiado por ser hospltaleiro para com os estrangeiros (Xénon, v. 11), o que volta a acontecer, aplicado aos Tindáridas, no primeiro verso da 3a. Olimplca (Tyndaridais te philoxelnois) e mais à frente, no verso 71 (xenlais trapézals).

Nåo julgaria que tal recorrência, nas odes em questăo, fosse fortulta - com base, por exemplo, apenas em dados gerais como a importancia atribulda polos gregos à virtude da hospitalidade - mas que deva remeter a própria experiencia do poeta como xénos recebido nas cortes daqueles que canta, nas quais encontrará esp̣aço pära 
exercer sua arte, Quando compoe essas trés odes, Píndaro está no início de sua experiência como xénos na Siclia. Para além disso, contudo, o poeta é xénos por, năo pertencendo ao clrculo dos rels, associar-se a eles para cantá-los:

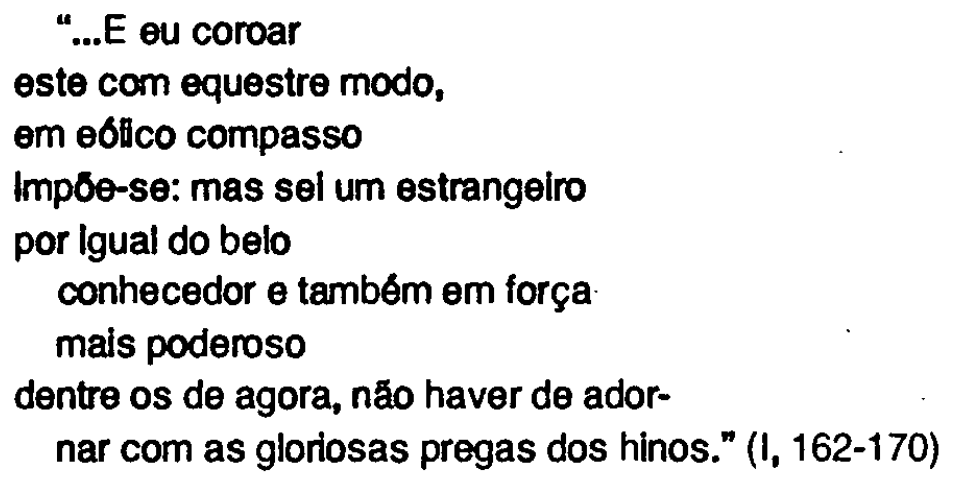

A missáo do poeta se impoe, nesse caso, como a necessidade (khré, v. 165) de cantar estrangeiros (xénoi) distinguidos pelo gosto do belo e pelo poder de sua força (dynamis). Ora, enquanto também o poeta possui essas características, enquanto cultiva o belo e tem na sua arte sua dynamis, $\theta$ o mesmo que o rei. Mas a qualidade de estrangeiro - aqui entendida na dinâmica de relaçбes bipessoais, ou seja, o rei é o estrangeiro do poeta como este daquele - é que determina a individualidade de cada um em face do outro. Na alteridade das excelências que thes são próprias, rei e poeta se associam no brilho da glória que os hinos perenizam, rei e poeta póem o que têm de melhor em sua dynamis a serviço do vir a ser dos hinos. $O$ que se encontra além desses extremos

$$
\begin{aligned}
& \text { "...é aos sábios inacessivel } \\
& \text { e tambem aos náo sábios" (III, 81-82). }
\end{aligned}
$$

Por esse motivo, termina o autor, delimitando bem o objetivo de seu canto num programa de conteúdo.

$$
\text { “...năo o perseguirei: fútil seria" (III, v. 82). }
$$




\section{BIBLIOGRAFIA}

\section{TEXTOS}

PINDARE. Olympiques. Texte Établie et traduit par A. Puech. Paris, Les Belles Lettres, 1970.

\section{ESTUDOS:}

ADRADOS, F.R.EI mundo de la lírica griega antigua. Madrid, Allanza, 1981.

BASLEZ, M.F.L'étranger dans la Grece antique Paris, Les Belles Lettres, 1984.

DUCHEMIN, J.Pindare, poète et prophète. Paris, Les Belles Lettres, 1955.

FINLEY Jr., J. H.Pindar and Aeschylus. Cambridge, Harvard University Press, 1966.

LESKY, A.Geschichte der griechischen Literatur. Bern, Francke, 1971.

MALHADAS, D.Pindaro: odes aos príncipes da Sicflia. Araraquara, UNESP, 1976.

SNELL, B.La cultura greca e le origini del pensiero europea. Trad. di V. Degll Alberti. Torino, Einaudi, 1951. 